September 2019).

11. Olejnikov E. A. (1997) Osnovy ekonomicheskoj bezopasnosti [Fundamentals of Economic Security]. Moskva. (in Russian) 12. Ilyashenko S. I. (2003) Sostavlyayushhie ekonomicheskoj bezopasnosti predpriyatiya i podxody` k ix ocenke [Components of economic security of enterprises and approaches to their assessment]. Aktualni problemi ekonomiki, no. 3 (21), pp. 12-19. (in Russian)

13. Kuzenko T. B. (2004) Taktychne i stratehichne planuvannia ekonomichnoi bezpeky pidpryiemstva [Tactical and strategic planning of economic security of the enterprise]. Aktualni problemy ekonomiky, no. 3, pp. 142-151. (in Ukrainian)

14. Prokopishyna O. V. (2009) Upravlinnia ekonomichnoiu bezpekoiu zovnishnoekonomichnoi diialnosti pidpryiemstva. [Management of economic security of foreign economic activity of the enterprise]. Ph.D. in Econ. Dissertation, Kharkiv: Kharkivskyi natsionalnyi ekonomichnyi universytet. (in Ukrainian)

15. Belokurov V. V. (2005) Struktura funktsyonalnikh sostavliaiushchykh эkonomycheskoi bezopasnosty predpryiatyia [Structure of functional components of economic security of the enterprise]. Available at http://snku.krok.edu.ua/index.php/vcheni-zapiskiuniversitetu-krok/article/view/12 (accessed 13 September 2019). (in Russian)

16. Shtanhret A. M. and Petrashova O. M. (2011) Kliuchovi zahrozy zabezpechennia tekhniko-tekhnolohichnoi bezpeky na pidpryiemstvakh vydavnycho-polihrafichnoi haluzi Ukrainy [Key threats to technical and technological security at enterprises of the publishing and printing industry of Ukraine]. Ekon. visnyk universytetu, no. 16 (2), pp. 142-146. (in Ukrainian)

17. Chimitova A. B. and Mikulchinova E. A. (2007) Voprosy ustojchivogo i bezopasnogo razvitiya regiona [Issues of sustainable and safe development of the region]. Ulan-Ude: VSGTU. (in Russian)

18. Varnalii Z. S., Burkaltseva D. D. and Saienko O. S. (2011) Ekonomichna bezpeka Ukrainy: problemy ta priorytety zmitsnennia [Economy of Ukraines security: problems and priorities]. Kyiv: Znannia Ukrainy. (in Ukrainian)

19. Bendikov M. A. (2000) Ekonomicheskaya bezopasnost promyshlennogo predpriyatiya $\mathrm{v}$ usloviyax krizisnogo razvitiya [Economic security of an industrial enterprise in conditions of crisis development]. Menedzhment v Rossii i za rubezhom, no. 2, pp. 17-29. (in Russian)

20. Afoncev S. (2002) Natsyonalnaia эkonomycheskaia bezopasnost: na puty k teoretycheskomu konsensusu [National economic security: Towards a theoretical consensus]. Mirovaya ekonomika i mezhdunarodnye otnosheniya, no. 10, pp. 30-39. (in Russian) 21. Tarasevych V. M. (2009) Natsionalna ekonomika [National economy]. Kyiv: Tsentr uchbovoi literatury. (in Ukrainian)

22. Lazareva A. P. (2012) Finansovo-ekonomichna bezpeka pidpryiemstva ta mekhanizm yii zabezpechennia [Financial and economic security of the enterprise and the mechanism of its provision]. Innovatsiina ekonomika, no. 2 (6), pp. 305-307. (in Ukrainian)

Рецензент д.е.н., професор Маркіна I.A.

УДК: 631.15(477) : 005.59

Дорофєєв О.В., к.е.н., доцент

Шелковський В.Д., Летик А.І., здобувачі вищої освіти СВО «Магістр»

Полтавська державна аграрна академія

\title{
КОНЦЕПТУАЛЬНІ ОСНОВИ УПРАВЛІННЯ ЕКОНОМІЧНИМ РОЗВИТКОМ СІЛЬСЬКОГОСПОДАРСЬКИХ ПІДПРИЕМСТВ НА ПРИНЦИПАХ ГАРМОНІЙНОСТІ
}

У статті розглянуто історичні аспекти виникнення криз аграрного виробництва. Зроблено припущення, що аграрна криза є свідченням порушення економічних пропорцій в системі аграрного виробництва. Взаємозв'язок і співвідношення певних показників економічної діяльності підприємств має відбуватися із дотриманням пропорцій у процесі зміни стану системи. Мова йде не про встановлення оптимальних значень показників, а про управління економічним розвитком сільськогосподарських підприємств та забезпечення їх ефективного функціонування у довгостроковому періоді на принципах гармонійності.

Ключові слова: управління розвитком, економічний розвиток, принципи гармонійності, сільськогосподарські підприємства.

Dorofyeyev O., Shelkovskyi V., Letyk A.

\section{CONCEPTUAL BASIS OF MANAGEMENT OF ECONOMIC DEVELOPMENT OF AGRICULTURAL ENTERPRISES ON THE PRINCIPLES OF HARMONY}

The historical aspects of occurrence of crises in agricultural production are considered in the article. The assumption that the agrarian crisis is evidence of a violation of economic proportions in the agricultural production system was made. The interconnection and correlation of certain indicators of enterprises economic activity should be kept in accordance with the proportions in the process of changing the system state. It is not about setting the optimum indicators value, but about managing the economic development of agricultural enterprises and ensuring their effective functioning in the long term on the principles of harmony. enterprises.

Keywords: development management, economic development, principles of harmony, agricultural 
Дорофеев А. В., Шелковський В. Д., Летик А. И.

\section{КОНЦЕПТУАЛЬНЫЕ ОСНОВЫ УПРАВЛЕНИЯ ЭКОНОМИЧЕСКИМ РАЗВИТИЕМ СЕЛЬСКОХОЗЯЙСТВЕННЫХ ПРЕДПРИЯТИЙ НА ПРИНЦИПАХ ГАРМОНИЧНОСТИ}

В статье рассмотрены исторические аспекты возникновения кризисов аграрного производства. Сделано предположение, что аграрный кризис является свидетельством нарушения экономических пропорций в системе аграрного производства. Взаимосвязь и соотношение определенных показателей экономической деятельности предприятий должно происходить с соблюдением пропорций в процессе изменения состояния системы. Речь идет не об установлении оптимальных значений показателей, а об управлении экономическим развитием сельскохозяйственных предприятий и обеспечения их эффективного функционирования в долгосрочном периоде на принципах гармоничности.

Ключевые слова: управление развитием, экономическое развитие, принципы гармоничности, сельскохозяйственные предприятия.

Постановка проблеми у загальному вигляді i iï зв'язок 3 важливими науковими та практичними завданнями. Із утвердженням ринкових принципів організації господарського життя в Україні стало зрозумілим, що існуючі концепцій управління не є універсальними. Це сприяло швидкому формуванню досить скептичного ставлення до нібито раціонального характеру поведінки підприємств.

Недосконалість «людини в світі», яку відмічали Фіхте, Ніцше, Шеллінг та інші філософи, найбільш виразно окреслена в працях Канта, який висунув тезу про необхідність обмеження практичних дій людини моральним категоричним імперативом. Усе частіше про моральні принципи формування господарського життя, 3 огляду на кризу ринкового устрою економіки, згадують і сучасні дослідники: «Для цього важливо подолати абсолютизацію речової залежності людей і фетишизацію прибутку, грошей, матеріального предметно-речового виду виробництва та нагромадження, коли люди, схиляючись перед багатством, не $є$ дійсно вільними суб'єктами і творцями суспільних відносин, коли людина служить тільки матеріальному виробництву, пристосовуючи до нього саму себе і природу» [1, с. 12].

Та все ж зростання значення позаекономічних чинників впливу на функціонування аграрних господарських систем в режимі сталості не припиняє наукового пошуку економічних можливостей забезпечення їх розвитку. Насамперед йдеться про застосування кількісного аналізу для прийняття обгрунтованих управлінських рішень на основі методології управління гармонійним розвитком.

Аналіз останніх досліджень, у яких започатковано вирішення проблеми. Методологічним основам та загальним принципам управління економічним розвитком підприємств присвячені роботи С. Брю [2], Л. Канторовича [3], К. Макконнелла [2], А. Маршалла [4], Й. Шумпетера [5] та інших.

Отримані названими та іншими авторами результати досліджень $є$ важливими 3 точки зору розуміння соціально-економічних відносин і вирішення проблем управління на принципах гармонійності, але безперечно потребують подальшого розвитку, особливо стосовно сільськогосподарських підприємств.

Цілі статті. Ціллю статті $є$ дослідження концептуальних основ управління економічним розвитком сільськогосподарських підприємств на принципах гармонійності.

Виклад основного матеріалу дослідження 3 повним обгрунтуванням отриманих наукових результатів. Якщо звернутися до історії становлення сільськогосподарських підприємств на основі приватнокапіталістичного дрібнобуржуазного виробництва, то не важко помітити, що цей процес супроводжувався постійним порушенням кількісних співвідношень між окремими параметрами виробничої системи, яке розглядалося як криза аграрного виробництва. Економістиаграрники кінця XIX ст. здебільшого вважали аграрні кризи ознакою непридатності 
землеробства до ринкових умов, доказом неефективності капіталістичного способу виробництва в сільському господарстві $[6 ; 7]$. Проте, більш цікавим і співзвучним сьогоднішнім уявленням про механізми розвитку систем, був погляд учених на аграрні кризи як на суспільні зрушення, які стимулюють розвиток продуктивних сил. Одна 3 перших спроб визначення кризи як етапу в розвитку аграрної економіки, який дає поштовх технологічній трансформації сільського господарства належить О. І. Скворцову [8]. На початку XX ст. зменшення цін на продовольчу сировину і зниження внаслідок цього ефективності сільськогосподарського виробництва дало нове життя теорії спадної родючості грунту (Р. Торренс, Т. Мальтус, Д. Рікардо та інш.), яка трансформувалася в теорію спадної віддачі на капітал [2; 4]. До речі, К. Макконнел і С. Брю тенденцію до зниження родючості землі називали ще «законом пропорцій, що змінюються» [2]. Отже, можна допустити, що аграрна криза є свідченням порушення економічних пропорцій в системі аграрного виробництва, які намагаються відновити за допомогою впровадження у виробництво інновацій або за допомогою методів макроекономічного регулювання.

Після Другої Світової війни великі надії покладалися на розвиток міжнародної торгівлі, і насправді, завдяки більш вільному пересуванню товарів було досягнуто значного прогресу в галузі аграрного виробництва, яка в різних країнах отримала технологічну підтримку саме за рахунок торгівлі між країнами. У той же час міжнародна торгівля сприяла поглибленню економічної нерівності між країнами. «Експорт, особливо якщо він сільськогосподарський, не здатен генерувати достатню купівельну спроможність для індустріалізації, отже наслідки торгівлі факторами виробництва не вигідні для тропічних країн», пише У. А. Льюіс [9]. Візьмемо на себе сміливість зазначити, що вони не вигідні усім малорозвиненим країнам.

У радянський період причиною усіх аграрних криз визнавалося протиріччя між суспільним характером виробництва і приватним способом присвоєння благ, що, однак, не пояснювало причини неефективності аграрного виробництва радянського періоду, яке такої вади не мало. 3 середини XX ст. спостерігаються спроби використати для визначення параметрів виробництва можливості математичного моделювання. Використання математичного моделювання в практиці економічної діяльності, хоча i показало позитивні результати, усе ж з меншим успіхом використовувалося в аграрній сфері. Я. Тінберген, один із засновників економетричного моделювання, визнавав як високу залежність результатів моделювання від випадкових відхилень, так i недоцільність їх використання при певних умовах. Коментуючи незадовільні результати застосування моделювання в сільському господарстві, він писав: «...річні коливання цін на яловичину вдалось хоч якось задовільно пояснити, лише ввівши в модель лагові ціни на фураж, причому з від'ємним значенням. Виявилося, що високі ціни на фураж змушують селян забивати частину худоби, що сприяє зниженню цін на м'ясо. Ні я, ні мої колеги навіть не підозрювали про це...» [9]. Обгрунтовуючи перспективи економетричного моделювання, Я. Тінберген наголошує на доцільності введення в моделі змінних просторового і соціального характеру, що зближує економетричний підхід з концептуальними положеннями моделі сталого розвитку економіки. Найбільш цінним в зауваженнях Я. Тінбергена, на наш погляд, є визнання пріоритетності фундаментальних досліджень економічних процесів над прикладними. Причому, дослідження мають торкатися економіки багатьох країн, які відрізняються інститутами, а отже й інституціональними витратами на врегулювання відносин між суб'єктами економіки. Звернемо також увагу на зростання багатофакторності моделей.

На початку XX ст. сформувалася й ще одна тенденція, важлива у контексті генези концепції управління гармонійним розвитком - зростання значення масивів статистичних даних: «... 3 цього часу економічна наука вступила в стадію, на якій природничі науки знаходилися вже давно, - а саме, в стадію, коли теоретичні концепції створюються на основі емпіричних спостережень, а розвиток теорії, своєю чергою, сприяє удосконаленню техніки спостережень» [9, с. 57-58]. Зважаючи на багатофакторність аграрного виробництва i множинність його цілей, ключовим 
моментом економічних досліджень стає виявлення сили впливу усіх факторів на процес виробництва. Інколи ми маємо справу лише з наслідками цих впливів $\mathrm{i}$, якщо вони незадовільні, урядами застосовується ряд заходів регуляторного характеру, спрямованих на поліпшення ситуації. Так, технологічне оновлення аграрних підприємств в Україні сприяло суттєвому зменшенню потреби в робочій силі, зростанню безробіття і сільській міграції (табл. 1).

Негативні наслідки структурних зрушень в аграрній економіці України відмічаються практично усіма дослідниками, але конфліктність процесу економічного зростання є притаманною економікам усіх країн. «Економічне зростання неминуче викликає втрату відносних позицій цілого ряду груп населення - фермерів, дрібних виробників, землевласників - які нелегко сприймають ці зміни, а насправді, як показує історія, часто з ними намагаються боротися» [9, с. 112]. Очевидно, що для забезпечення подальшого економічного розвитку суб'єктів аграрного виробництва мають бути використані і можливості державного апарату щодо побудови соціальної політики. За постійного технологічного оновлення, характерного для сучасного етапу розвитку економіки, без використання відповідних йому соціальних новацій, важко очікувати позитивних суспільних зрушень.

Таблиця 1.

Динаміка чисельності найманих працівників та заробітної плати в аграрному секторі економіки України, 2004-2018 pр.

\begin{tabular}{|c|c|c|c|c|c|c|c|}
\hline \multirow{2}{*}{ Показники } & \multicolumn{6}{|c|}{ Роки } & \multirow{2}{*}{$\begin{array}{c}2018 \text { р. до } \\
2004 \text { р., \%, } \\
\text { рази }\end{array}$} \\
\hline & 2004 & 2008 & 2012 & 2016 & 2017 & 2018 & \\
\hline $\begin{array}{l}\text { Кількість зайнятого } \\
\text { населення, тис. осіб }\end{array}$ & 298,3 & 3322,1 & 3308,5 & 2866,5 & 2860,7 & 2937,6 & 73,5 \\
\hline $\begin{array}{l}\text { Кількість найманих } \\
\text { працівників, тис. осіб }\end{array}$ & 1272 & 783 & 697,8 & 583,4 & 558,1 & 540,5 & 42,5 \\
\hline $\begin{array}{l}\text { Середньомісячна } \\
\text { заробітна плата в } \\
\text { Україні, грн }\end{array}$ & 590 & 1806 & 3026 & 5183 & 7104 & 8865 & $15 \mathrm{p}$. \\
\hline $\begin{array}{l}\text { Середньомісячна } \\
\text { заробітна плата в } \\
\text { сільському, лісовому та } \\
\text { рибному господарстві, } \\
\text { грн }\end{array}$ & 311 & 1101 & 2086 & 4195 & 6057 & 7557 & $24 \mathrm{p}$ \\
\hline
\end{tabular}

Джерело: побудовано автором за даними Державної служби статистики України.

Картина економічного життя весь час стає складнішою: урізноманітнюються технології і товари, складаються нові форми виробництва і виробничої взаємодії, виникають нові соціальні групи, державні інститути поступово вбудовуються в господарські системи, а отже зростає потреба в господарській (і не лише) координації. Не зупиняючись детально на ринковій координації, яка здійснюється на підставі цінового механізму, зазначимо, що на сьогоднішній день вона не є задовільною $з$ точки зору соціальної справедливості і цей факт раз за разом змушує дослідників повертатися до теорії державного регулювання економіки. Недосконалість ринкової координації, спрямованої на забезпечення ефективності, визнають навіть іiі прихильники: «...ефективність за Парето жодним чином не передбачає розподільної справедливості. Розподіл ресурсів може бути ефективним, в сенсі Парето, і в той же час породжувати нечуване багатство в одних і жорстку злиденність у інших» [9, с. 144]. Вади ринкового механізму намагалися мінімізувати методами оптимізації, поєднуючи їх з положеннями теорії раціонального вибору, оскільки уже був зрозумілим взаємозв'язок між пропозицією, попитом і цінами.

Велике значення для розвитку методології оптимізації економічних процесів мала робота Л. Канторовича «Математичні методи організації та планування виробництва» 
[3]. Л. Канторович зробив цікавий висновок про те, що результати діяльності однієї і тієї ж виробничої системи можуть бути отримані завдяки використанню різних технологічних процесів. 3 цього можна вивести принаймні два положення:

- оптимізацію як інструмент обгрунтування управлінських рішень доцільно використовувати не по відношенню до усієї системи, а по відношенню до окремого технологічного процесу, який і є системою з певними параметрами;

- може одночасно існувати декілька оптимумів виробництва (за різних заданих умов), що дозволяе припустити наявність чогось спільного в різних способах виробництва і це точно не абсолютні величини різних показників.

Іще раз звернемо увагу на дані, наведені в таблиці 1, ми бачимо, що протягом майже 15 років потреба в найманих працівниках сільського, лісового і рибного господарства скоротилася майже на $60 \%$, що частково компенсувалося самозайнятістю у цій же сфері; середньомісячна заробітна плата найманих працівників за цей же період зросла в 24 рази - це на 9 більше, ніж у середньому по економіці України. Значна частина наслідків глобальних структурних зрушень, що відбувалися у сфері аграрної економіки протягом усього періоду становлення незалежності України, має негативну оцінку: зменшення зайнятості безпосередньо в сільському господарстві і зростання безробіття; відокремлення виробничої діяльності від соціального життя в сільській місцевості; обмежене право власності на землю, нечітко розподілені складові права власності на землю між суб'єктами аграрних відносин, унаслідок чого вони уникають відповідальності за погіршення якості земельних ділянок; формування дрібнотоварного способу виробництва, що не відповідав рівню розвитку продуктивних сил, а тому швидко трансформувався в агрохолдингову організацію сільськогосподарського виробництва тощо. Оціночні висновки супроводжувалися рекомендаціями щодо виправлення ситуації (повернення до існувавшого стану стосовно зайнятості, структури виробництва, галузевого управління), проте мало хто із науковців задавався питанням: чи доцільним є збереження параметрів виробництва в нових умовах? Чи можливо така серйозна зміна величин показників діяльності сільськогосподарських підприємств припустима в тому випадку, коли між темпами зміни цих величин зберігаються певні пропорції?

До речі, дослідження оплати праці в аграрних підприємствах і зміни іï частки у структурі виробничих витрат практично завжди супроводжувалося використанням порівняння динаміки зміни заробітної плати і продуктивності праці, без чого неможливо надати обгрунтовані рекомендації щодо удосконалення системи заробітної плати в підприємствах аграрного сектору економіки. Існує єдність поглядів стосовно того, що продуктивність праці має змінюватися (зростати) випереджувальними темпами у порівнянні з оплатою праці, проте відкритим залишається питання відносно величини цього випередження. Встановлені причинно-наслідкові зв'язки між оплатою праці, продуктивністю праці, витратами виробництва, цінами, інфляцією, попитом, податками і бюджетними витратами держави вказують на складність розв'язання проблеми оплати праці, яка виступає найголовнішим мотиваційним чинником виробничих систем.

Б. Улін зауважує, що в довгостроковій перспективі головною проблемою скоординованого управління господарською діяльністю підприємств стає «...попередження надмірного підвищення заробітної плати» [9, с. 276]. На прикладі економіки Швеції Улін доводить, що зростання витрат на оплату праці негативно позначається на виробництві та зайнятості і приводить до його спаду та стагнації. Ми знову наштовхуємося на проблему дотримання пропорцій у процесі зміни стану системи.

Якщо порівняти темпи зростання оплати і продуктивності праці в сільському господарстві України, то помітно, що протягом п'яти років ситуація змінилася на протилежну: до 2014 р. вищими були темпи зростання продуктивності праці, після оплати праці, що було викликано порушенням цінових пропорцій на ринку та інфляцією (рис. 1). 3 точки зору економічної логіки важливо, щоб темпи зростання продуктивності праці були вищими, ніж темпи зростання іiї оплати, але на скільки? Чи є динаміка зміни 
оплати праці в сільському господарстві, наведена на рис. 1, визнанням критичної важливості людського фактору у забезпеченні подальшого розвитку суб'єктів аграрного виробництва і аграрної економіки в цілому? Розмірковуючи над цим питанням, доцільно відштовхнутися від досліджень Т.У. Шульца, який доводив, що аграрна політика держави у багатьох випадках спрямовується на підтримку менш численного міського населення за рахунок економічної дискримінації більш численних сільських товаровиробників [10].

Але сучасний період відрізняється зміною співвідношення між сільським і міським населенням на користь останнього і можливо вищі темпи зростання оплати праці в сільському господарстві є реакцією на цю зміну? Без додаткових досліджень ми не можемо стверджувати про зниження трудового потенціалу аграрних підприємств, та порівняно вищі темпи збільшення оплати праці в галузі свідчать збільшення уваги до якості людського капіталу. Поліпшення якості людського капіталу пов'язано 3 додатковими витратами, тому достатньо часто виникає дефіцит працівників потрібного кваліфікаційного рівня, що підвищує їх економічну цінність. Здібності людини, що обумовлюють розподіл ресурсів, важливі для будь-якого виробництва, зокрема й для сільськогосподарського [10].

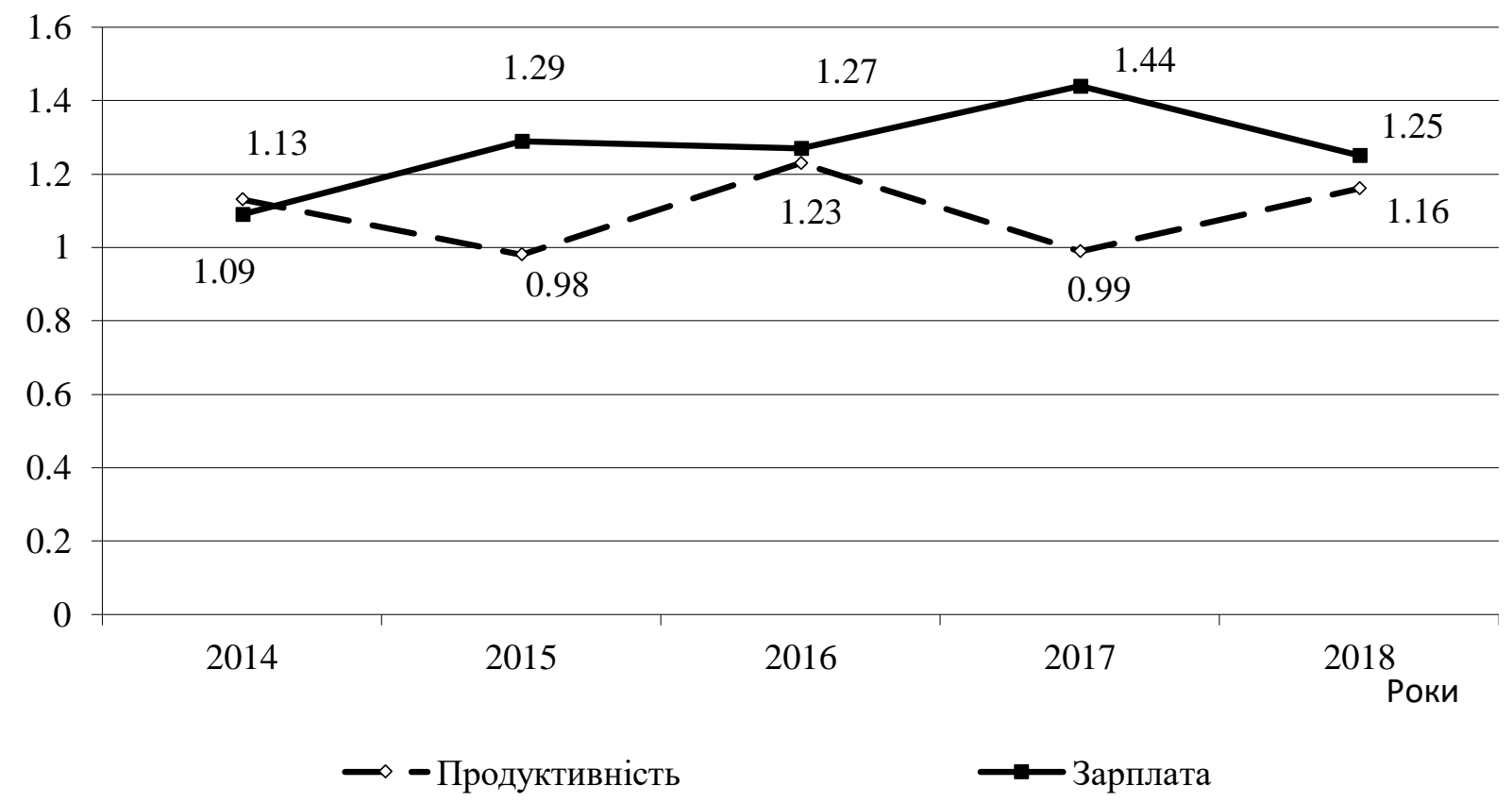

Рис. 1. Індекси оплати і продуктивності праці в сільському господарстві України (до попереднього року), 2014-2018 рр.

Джерело: побудовано автором заданими Державної служби статистики України.

Відмічаючи порушення у співвідношенні окремих елементів системи аграрного виробництва, частина авторів схильна наголошувати на новій аграрній кризі, надаючи тенденціям негативної оцінки [11] і знаходячи відмінності у причинах кризових явищ у порівнянні з кінцем XX - початком XXI ст. Стає зрозуміло, що витоки аграрних криз обумовлюються різноманітними причинами, які важко піддаються систематизації і які можуть перебувати як ззовні, так і всередині системи. До того ж, виникнення імпульсів до змін не має чітко вираженої періодичності, що помітив ще Й. Шумпетер, який, у зв'язку з цим, визнавав обмеженість статичного аналізу: «... «статичний» аналіз не лише неспроможний передбачити наслідки дискретних змін у традиційному господарюванні - він нездатен також пояснити факт виробничих революцій та супровідні явища» [5, с. 72]. «Спонтанні й дискретні зміни у шляхах перебігу економічного життя, порушення 
рівноваги, які назавжди змінюють і замінюють попередній стан рівноваги» [там само, с. 73-74] Й. Шумпетер визначав як розвиток, наполягаючи, до того ж, що ці зміни обов'язково мають відбуватися всередині системи.

Якщо ендогенні зміни прогнозовано будуть відбуватися, але вони залишатимуться непрогнозованими у часі, чи не можна якимось чином збалансувати між собою показники виробничої діяльності аграрних підприємств, щоб уникнути соціальних конфліктів? Пошук у цьому напрямі здійснювали як зарубіжні, так і вітчизняні учені [11; 12], запропонувавши для практичного використання метод збалансованої системи показників. Метод, який передбачав здійснювати стратегічне управління підприємствами на основі взаємоузгодження чотирьох груп показників (фінансових, клієнтурних, операційних і кадрових), був на початку 90-х років оприлюднений Р. Капланом і Д. Нортоном [12]. У вітчизняному науковому середовищі метод отримав поширення зусиллями О. Ліссітси та інш. [11].

Обстоюючи доцільність запровадження методу збалансованих показників в управління розвитком суб'єктів аграрного виробництва в Україні, О. Ліссітса зазначає, що метод, за допомогою пов'язаних між собою показників, дозволяє визначити розвиток підприємства із врахуванням причинно-наслідкових зв'язків. Метод дозволяє оцінити як показники минулої діяльності підприємства, так і стратегічно важливі параметри його стану в майбутньому [11].

Висновки. Слід відмітити, що мова не йде про встановлення оптимальних значень показників, автори методу та їх послідовники наголошують лише на необхідності враховувати наявні причинно-наслідкові зв'язки між економічними та соціальними складовими системи при прийнятті управлінських рішень, а також наводять перелік показників за визначеними напрямами. Аналіз економічної динаміки i пошук «правильних» параметрів функціонування динамічних систем сприяли поглибленню наукових знань щодо оптимальності господарських процесів, ринкової рівноваги, сталості (збалансованості) розвитку тощо, але лише в останнє десятиріччя з'являється критична кількість публікацій, присвячених управлінню на принципах гармонійного розвитку, що змушує більш уважно вивчати концепцію гармонійного розвитку з метою удосконалення теорії управління економічним розвитком аграрних підприємств та забезпечення їх ефективного функціонування у віддаленому періоді.

\section{Список бібліографічного опису:}

1. Оскольський В. Раціональне природокористування - важлива умова ноосферного розвитку України. Економіка Украӥни. 2011. № 11. С. 4-13.

2. Макконнелл К. Р., Брю С. Л. Экономикс: Принципы, проблемы и политика. Москва, 1996. 400 с.

3. Канторович Л.В. Математические методы организаџии и планирования производства. Ленинград, $1992.67 \mathrm{c.}$

4. Маршалл А. Принциипы экономической науки: в 3 т. Т.1. Москва, 1993. 416 с.

5. Шумпетер Й.А. Теорія економічного розвитку: Дослідження прибутків, капіталу, кредиту, відсотка та економічного ииклу. Київ, 2011. 242 с.

6. Каблуков Н.А. Вопрос о рабочих в сельском хозяйстве. Москва, 1884. 299 с.

7. Tracy M. Agriculture in Western Europe Crisis and adaption since 1880. London: J. Cape, 1963. 415 p.

8. Скворцов А. Основания политической экономии. Санкт-Петербург, 1898. 432 с.

9. Нобелевские лауреаты по экономике: взгляд из России / Ред. Академик РАЕН, проф. Ю.В. Яковец. Санкт-Петербург, 2003. $968 \mathrm{c.}$.

10. Schultz T.W. On Economics and Politics of Agriculture. Bloomington: Indiana University Press, 1978. P. 3-23.

11. Сільське господарство України: криза та відновлення / За ред. Штефана фон Крамона-Таубаделя, Сергія Дем'яненка, Арніма Куна. Київ: Гарант-Сервіс, 2004. 207 с.

12. Kaplan R.S., Norton D.P. The Balanced Scorecard as a strategic management system. Harvard Business Review. 1992. January-February. P. 61-66.

\section{References:}

1. Oskolskyi V. (2011). Ratsionalne pryrodokorystuvannia - vazhlyva umova noosfernogo rozvytku Ukrainy [Rational use of nature is an important condition for the noospheric development of Ukraine]. Ekonomika Ukrainy - Economy of Ukraine, 11, 4-13. [in Ukrainian].

2. McConnell C. R., Brue S. L. (1996). Ekonomiks: Printsypy, problem i politika [Economics: Principles, Problems, and Policies]. Moskva: Turan. Vols. 2: Vol. 2. [in Russian]. 
3. Kantorovich L. V. (1992). Matematicheskiye metody organizatsii i planirovaniya proizvodstva [Mathematical methods of production organization and planning]. Leningrad: Leningradskiy gosudarstvennyu universitet. [in Russian].

4. Marshall A. (1993). Printsypy ekonomicheskoy nauki [Principles of Economics]. Moskva: Izdatelskaya gruppa Progress. Vols. 3: Vol. 1. [in Russian].

5. Schumpeter J.A. (2011). Teoriia ekonomichnogo rozvytku: Doslidzhennia prybutkiv, kapitalu, kredytu, vidsotka ta ekonomichnogo tsyklu [The Theory of Economic Development: An Inquiry into Profits, Capital, Credit, Interest and the Business Cycle]. Kyiv: Vydavnychii dim "Kyievo-Mogylianska akademia". [in Ukrainian].

6. Kablukov N. A. (1884). Vopros o rabochikh v selskom khoziaystve [The question of workers in agriculture]. Moskva: redaktsyia "Yuridicheskogo Vestnika". [in Russian].

7. Tracy M. (1963). Agriculture in Western Europe Crisis and adaption since 1880. London: J. Cape. [in English].

8. Skvortsov A. (1898). Osnovaniya politicheskoy ekonomii [Grounds for political economy]. Sankt-Peterburg: tipografiya I. Goldberga. [in Russian].

9. Yakovets Yu. V. (Eds.). (2003). Nobelevskiye laureaty po ekonomike: vzglyad iz Rossii [Nobel Laureates in Economics: A View from Russia]. Sankt-Peterburg: Izdatelstvo "Gumanistika". [in Russian].

10. Schultz T.W. (1978). On Economics and Politics of Agriculture. Bloomington: Indiana University Press. P. 3-23. [in English].

11. Schtefan fon Kramona-Taubadel, Demianenko S., Kaun A. (Eds.). (2004) Silske gospodarstvo Ukrainy: kryza ta vidnovlennia [Ukrainian agriculture: crisis and recovery]. Kyiv: Garant-Servis. [in Ukrainian].

12. Kaplan R.S., Norton D.P. (1992). The Balanced Scorecard as a strategic management system. Harvard Business Review. January-February. 61-66. [in English].

Рецензент д.е.н., професор Писаренко В.В.

УДК 330.11.001.76

Дячков Д.В., к.е.н., доцент

Простак О.С., Тенянко А.О., здобувачі вищої освіти СВО «Магістр»

Полтавська державна аграрна академія

\section{НАПРЯМИ ПІДВИЩЕННЯ ЕФЕКТИВНОСТІ УПРАВЛІННЯ ІННОВАЦІЯМИ У СІЛЬСЬКОГОСПОДАРСЬКИХ ПІДПРИЕМСТВАХ}

В статі охарактеризовано залежність сталого розвитку підприємств агропродовольчої сфери від результативності розробки, освоєння та поширення нововведень. Визначено найбільш загальну та широковживану класифікацію інновацій в агропродовольчій сфері за предметом та сферою застосування, відповідно до якої визначено чотири їх типи: селекційно-генетичні, виробничі, організаційно-управлінські та економічні, соціально-екологічні. Зважаючи на зазначені типи інновацій, охарактеризовано пріоритетні напрями активізації інноваційної діяльності в агропродовольчій сфері. Розроблено схему організаційноекономічного механізму інноваційного розвитку агропродовольчої сфери, основними складовими якого є: організаційно-економічна, інституційна, інструментальна, нормативно-правова, методична, соціальнопсихологічна та фінансово-економічна. Запропоновані стратегічні напрями підвищення ефективності управління інноваціями на сільськогосподарських підприємствах.

Ключові слова: аграрний комплекс, агроінновації, агропрдовольча сфера, ефективність, інновації, організаційно-економічний механізм, сільськогосподарське підприємство.

Diachkov D., Prostak O., Tenyanko A.

\section{DIRECTIONS OF INCREASING THE EFFICIENCY OF INNOVATION MANAGEMENT AT AGRICULTURAL ENTERPRISES}

The article describes the dependence of sustainable development of agro-food enterprises on the effectiveness of development and dissemination of innovations. The most common and widespread classification of innovations in the agro-food sector was defined by subject and scope, according to which four types were defined: breeding-genetic, industrial, organizational-managerial and economic, social-ecological. Considering these types of innovations, the priority directions of activation of innovative activity in the agro-food sphere were characterized. The scheme of organizational and economic mechanism of innovative development of agro-food sector has been developed, the main components of which are: organizational-economic, institutional, instrumental, normative-legal, methodical, social-psychological and financial-economic. Strategic directions for 